\title{
Correction to: The Role of IS in the Conflicting Interests Regarding GDPR
}

\author{
Timo Jakobi • Maximilian von Grafenstein · Christine Legner • Clément Labadie • \\ Peter Mertens $\cdot$ Ayten Öksüz $\cdot$ Gunnar Stevens
}

(c) The Author(s) 2021

\section{Correction to: Bus Inf Syst Eng 62(3):261-272 (2020) https://doi.org/10.1007/s12599-020-00633-4}

The article "The Role of IS in the Conflicting Interests Regarding GDPR “ written by Timo Jakobi, Maximilian von Grafenstein, Christine Legner, Clément Labadie, Peter Mertens, Ayten Öksüz, Gunnar Stevens was originally published Online First without Open Access. After publication in volume 62 , issue 3, page [261-272] the author decided to opt for Open Choice and to make the article an Open Access publication. Therefore, the copyright of the article has been changed to (C) (CThe Author(s) 2021 and the article is forthwith distributed under the terms of the Creative Commons Attribution 4.0 International License,

The original article can be found online at https://doi.org/10.1007/ s12599-020-00633-4.

Dr. T. Jakobi $(\varangle) \cdot$ Prof. Dr. G. Stevens

Information Systems Esp. IT-Security and Privacy, University of

Siegen, Siegen, Germany

e-mail: timo.jakobi@uni-siegen.de

Prof. Dr. M. von Grafenstein

Berlin University of the Arts, Einstein Center Digital Future,

Berlin, Germany

Prof. Dr. C. Legner - C. Labadie

Faculty of Business and Economics (HEC), University of

Lausanne, Lausanne, Switzerland

Prof. Dr. Dr. hc. mult. P. Mertens

School of Business, Economics and Society and Faculty of

Engineering, University of Erlangen-Nuremberg, Nuremberg,

Germany

Dr. A. Öksüz

Consumer Association of North Rhine-Westphalia, Düsseldorf,

North Rhine-Westphalia, Germany which permits use, sharing, adaptation, distribution and reproduction in any medium or format, as long as you give appropriate credit to the original author(s) and the source, provide a link to the Creative Commons licence, and indicate if changes were made. The images or other third party material in this article are included in the article's Creative Commons licence, unless indicated otherwise in a credit line to the material. If material is not included in the article's Creative Commons licence and your intended use is not permitted by statutory regulation or exceeds the permitted use, you will need to obtain permission directly from the copyright holder. To view a copy of this licence, visit http://creativecommons.org/licenses/by/4.0.

Open access funding enabled and organized by Projekt DEAL.

Open Access This article is licensed under a Creative Commons Attribution 4.0 International License, which permits use, sharing, adaptation, distribution and reproduction in any medium or format, as long as you give appropriate credit to the original author(s) and the source, provide a link to the Creative Commons licence, and indicate if changes were made. The images or other third party material in this article are included in the article's Creative Commons licence, unless indicated otherwise in a credit line to the material. If material is not included in the article's Creative Commons licence and your intended use is not permitted by statutory regulation or exceeds the permitted use, you will need to obtain permission directly from the copyright holder. To view a copy of this licence, visit http://creativecommons. org/licenses/by/4.0/. 